\title{
Multilevel tracheal granulomatosis with polyangiitis (GPA) lesions in a paediatric patient
}

\author{
Sevasti Konstantinidou (10 , ${ }^{1}$ Paula Coyle, ${ }^{1}$ Gargi Pandey, ${ }^{1}$ Colin Butler ${ }^{1,2}$
}

${ }^{1}$ Paediatric Otolaryngology, Great Ormond Street Hospital for Children, London, UK ${ }^{2}$ University College London Institute of Child Health, London, UK

\section{Correspondence to} Dr Sevasti Konstantinidou; sevastgk@hotmail.com

Accepted 21 January 2021
Check for updates

(C) BMJ Publishing Group Limited 2021. No commercial re-use. See rights and permissions. Published by BMJ.

To cite: Konstantinidou $S$, Coyle P, Pandey G, et al. BMJ Case Rep 2021;14:e241064. doi:10.1136/bcr-2020-

241064

\section{DESCRIPTION}

Granulomatosis with polyangiitis (GPA), previously known as Wegener's granulomatosis, is a multisystemic necrotising granulomatous vasculitis primarily affecting the small-sized and medium-sized vessels. It can affect any organ, including upper and lower airways, and it is usually associated with elevated antineutrophil cytoplasmic antibodies (ANCA). Paediatric GPA is rare with limited evidence in the literature. In children, there is female predominance and higher incidence of subglottic stenosis. ${ }^{1-5}$

In this case, a 14-year-old girl presented with a 4-week history of dry cough, fever, fatigue and reduced appetite followed by anterior right nasal pain. Following admission, a nasal septal lesion was discovered on examination and CT thorax showed cavitating lung lesions (figure 1). Initial differential diagnosis included GPA and granulomatous infections (ie, tuberculosis and fungal), but Mantoux and ANCA were negative. She subsequently developed few episodes of intermittent stridor which were triggered by the cough. Microlaryngobronchoscopy revealed multiple white firm lesions throughout the trachea from subglottis to main bronchi with lower trachea stenosis and malacia to $50 \%$ (figures 2 and 3). Nasal and tracheal biopsies showed abnormal inflammatory and necrotising process, most consistent with underlying deep vasculitis despite the absence of vascular inflammation in biopsy tissue. She was started on IV pulse methylprednisolone which was then switched to oral prednisolone. She improved dramatically after the steroids and antibiotics. As of November 2020, she has been clinically

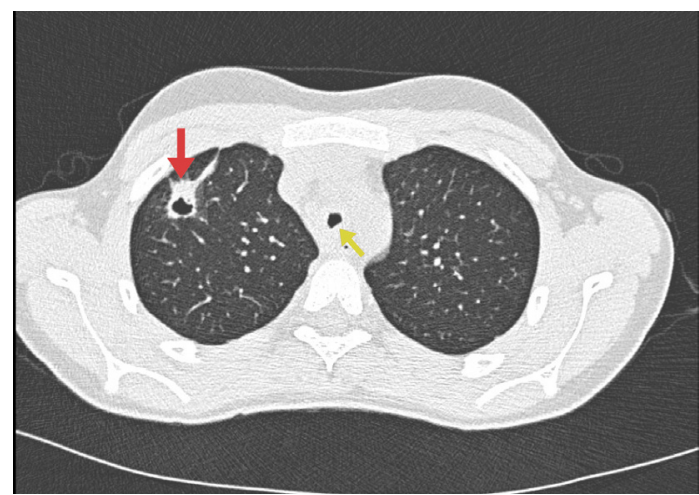

Figure 1 CT axial image in lung window at the level of the upper lobes. There is a soft tissue cavitating lesion in the upper right lobe with spiculated margins and thickened walls (red arrow). Also, there is thickening and nodularity of tracheal wall with left posterolateral bulging (yellow arrow).

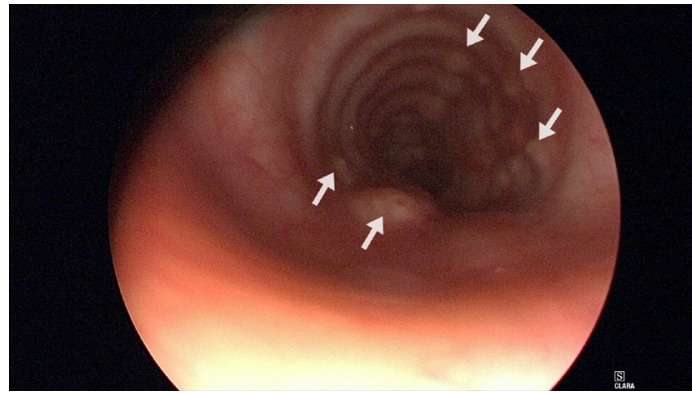

Figure 2 Multiple white firm lesions in subglottis as seen with microlaryngobronchoscopy.

well on oral prednisolone, following two doses of rituximab.

The incidence of subglottic stenosis in GPA has been estimated to be $8 \%-23 \%$ in total. Stenosis is more commonly limited to the subglottis and proximal trachea, but it can rarely extend into the distal trachea and bronchi. ${ }^{25}$ A study has revealed that multilevel stenosis involving subglottis and distal trachea presented in $6 \%$ of the cases. ${ }^{2}$ Clinically, patients can present with dyspnoea, stridor, cough or hoarseness, which may lead to misdiagnosis of asthma. ${ }^{15}$ Paediatric GPA is associated with a higher frequency of airway manifestations as compared with the adult GPA population. However, multilevel airway involvement is not commonly seen. ${ }^{13}$

The presence of ANCA is considered a very helpful diagnostic marker of GPA, with cytoplasmic ANCA found most of the times and perinuclear ANCA being less common. ${ }^{15}$ However, it is worth noting that ANCA testing can be negative in up to $40 \%$ of paediatric patients. ${ }^{4}$ GPA in children can present with sudden and progressive stridor and result in a life-threatening situation. It is therefore of paramount importance that clinicians are aware of its different manifestations and assessment

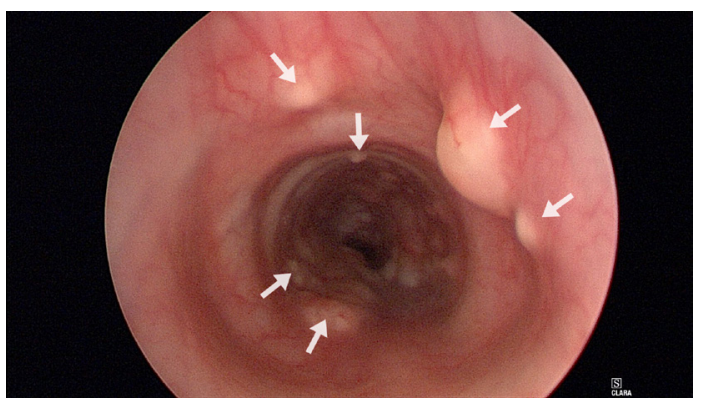

Figure 3 Multiple white firm lesions throughout the trachea from subglottis to main bronchi with lower trachea stenosis as seen with microlaryngobronchoscopy. 
steps. ${ }^{4}$ Management of tracheobronchial involvement in GPA that causes stenosis can include, apart from systemic therapy with corticosteroids and cytotoxic drugs, local steroid injection, stent, laser excision and balloon dilatation (cutting balloon). ${ }^{4-6}$

This case report shows a paediatric patient with ANCAnegative GPA presenting with extensive airway involvement with lesions throughout the trachea, hence highlighting that multilevel airway involvement in children with GPA is a rare but potential occurrence that can be clinically challenging.

\section{Learning points}

- Granulomatosis with polyangiitis (GPA) in children can present with sudden and progressive stridor.

- Testing for antineutrophil cytoplasmic antibodies can be negative in paediatric patients with GPA.

- Multilevel airway involvement in children with GPA is a rare but potential occurrence.

Acknowledgements The authors would like to thank Ms Aikaterini Foutaki for her contribution on editing the images.

Contributors SK contributed to collecting data, and writing and editing the manuscript. PC involved in patient's care and contributed to collecting data, and writing and editing the manuscript. GP contributed to writing and editing the manuscript. CB involved in patient's care and contributed to writing and editing the manuscript. All authors have contributed significantly to this manuscript and approved the latest version of the manuscript.

Funding The authors have not declared a specific grant for this research from any funding agency in the public, commercial or not-for-profit sectors.

Competing interests None declared.

Patient consent for publication Parental/guardian consent obtained.

Provenance and peer review Not commissioned; externally peer reviewed.

ORCID iD

Sevasti Konstantinidou http://orcid.org/0000-0001-6337-3160

\section{REFERENCES}

1 Fowler NM, Beach JM, Krakovitz P, et al. Airway manifestations in childhood granulomatosis with polyangiitis (Wegener's). Arthritis Care Res 2012:64:434-40.

2 Guardiani E, Moghaddas HS, Lesser J, et al. Multilevel airway stenosis in patients with granulomatosis with polyangiitis (Wegener's). Am J Otolaryngol 2015;36:361-3.

3 Eustaquio ME, Chan KH, Deterding RR, et al. Multilevel Airway Involvement in Children With Wegener's Granulomatosis. Arch Otolaryngol Head Neck Surg 2011;137:480.

4 Lee PY, Adil EA, Irace AL, et al. The presentation and management of granulomatosis with polyangiitis (Wegener's granulomatosis) in the pediatric airway. Laryngoscope 2017:127:233-40.

5 Girard C, Charles P, Terrier B, et al. Tracheobronchial stenoses in granulomatosis with polyangiitis (Wegener's). Medicine 2015:94:e1088-9.

6 Nouraei SAR, Mills $\mathrm{H}$, Butler CR, et al. Outcome of treating airway compromise due to bronchial stenosis with intralesional corticosteroids and cutting-balloon bronchoplasty. Otolaryngol Head Neck Surg 2011;145:623-7.

Copyright 2021 BMJ Publishing Group. All rights reserved. For permission to reuse any of this content visit

https://www.bmj.com/company/products-services/rights-and-licensing/permissions/

BMJ Case Report Fellows may re-use this article for personal use and teaching without any further permission.

Become a Fellow of BMJ Case Reports today and you can:

- Submit as many cases as you like

- Enjoy fast sympathetic peer review and rapid publication of accepted articles

Access all the published articles

Re-use any of the published material for personal use and teaching without further permission

Customer Service

If you have any further queries about your subscription, please contact our customer services team on +44 (0) 2071111105 or via email at support@bmj.com.

Visit casereports.bmj.com for more articles like this and to become a Fellow 